EREM 75/3

Journal of Environmental Research, Engineering and Management Vol. 75 / No. 3 / 2019 pp. 21-32 DOI 10.5755/j01.erem.75.3.24313
Agricultural Greenhouse Gas Emissions: Ukrainian Involvement in the Global Ecological Challenge

\begin{tabular}{|l|l}
\hline Received 2019/09 & Accepted after revision 2019/11 \\
\hline
\end{tabular}

\title{
Agricultural Greenhouse Gas Emissions: Ukrainian Involvement in the Global Ecological Challenge
}

\section{Natalia Vasylieva*}

Dnipro State Agrarian and Economic University, Department of Information Systems and Technologies

25 Serhiya Yefremova str., Dnipro, 49600, Ukraine

\section{Svitlana Sytnyk}

Dnipro State Agrarian and Economic University, Department of Agronomy

25 Serhiya Yefremova str., Dnipro, 49600, Ukraine

*Corresponding author: vasylieva.n.k@dsau.dp.ua

Greenhouse gas emission is a global ecological challenge since it affects climate change and complicates providing food security. Each country ought to care about mitigating greenhouse gas emissions including $\mathrm{CH} 4$ and N2O originated from agriculture. In this context, first, the performed research focused on Ukrainian ranking among the world greenhouse gas emitters offering a multi-criteria evaluation of total greenhouse gas quantities in $\mathrm{CO} 2$ equivalent, per capita and per km2 of countries' land territories. These indictors were also applied to visual comparing involvement of Ukrainian economy and its agriculture in the international greenhouse gas emissions. Second, to explore agricultural greenhouse gas emission at the domestic level, we studied regional contributions by basic source categories such as enteric fermentation, manure management, and synthetic fertilizers. The proposed horizontal and vertical analyses allow clarifying regional management priorities in reducing greenhouse gas emissions. Third, for this purpose, the conducted investigation specified the EU Member States which match the Ukrainian condition by shares of greenhouse gas emissions and outputs in animal and crop sectors. The found patterns will be the most reliable vectors of adopting effective agricultural practices beneficial for the environment protection and mitigating influence over climate change.

Keywords: agricultural GHG emissions, multi-criteria ranking, GHG distribution by regional sources, GHG mitigation in the EU agriculture. 


\section{Introduction}

Being adopted in New York in May 1992 and proclaimed on the Earth Summit held in Rio de Janeiro in June 1992, the United Nations Framework Convention on Climate Change (the UNFCCC) recognized the global challenge of human-induced impact on the climate system. At present, there are almost 200 countries which have approved and ratified the UNFCCC. Climate change in the form of global warming associates with greenhouse gas (GHG) emissions. The major anthropogenic GHGs are carbon dioxide $\left(\mathrm{CO}_{2}\right)$, methane $\left(\mathrm{CH}_{4}\right)$ and nitrous oxide $\left(\mathrm{N}_{2} \mathrm{O}\right)$ with the shares of $76 \%, 16 \%$, and $6 \%$, respectively. Besides, they are different not only in lifetime of 50,12 , and 120 years but also in initial radiative forcing in the ratio about 1:25:250 (UNFCCC, 2019). Since 1750, atmospheric concentrations of carbon dioxide, methane, and nitrous oxide (in parts per million $\left(\mathrm{CO}_{2}\right) /$ parts per billion $\left(\mathrm{CH}_{4}, \mathrm{~N}_{2} \mathrm{O}\right)$ ) increased by $45 \%, 156 \%$, and $22 \%$, respectively, and were entailed by raising the average global surface temperature by over 0.8 degrees Celsius. A current distribution of manmade GHG emissions by economic sectors looks like 31\% from electricity and heat; $29 \%$ from manufacturing, constriction, and industrial processes; 19\% from transportation, fuel combustion, and bunker fuels; $11 \%$ from agriculture; $6 \%$ from land use change and forestry; and $4 \%$ from waste (WB, 2019). Therefore, the international community have taken a decision to cooperate in further efforts to ease GHG emissions in compliance with the past Kyoto Protocol and the ongoing Paris Agreement.

The Kyoto Protocol entered into force in 1997 and was actually expired in 2012. It encouraged promoting, developing, and increasing use of "advances and innovative environmentally sound technologies" which ensure "real, measurable, and long-term benefits related to the mitigation of climate change" (The Kyoto Protocol, 1998). Over 190 countries joined the named agreement which defined a regulatory mechanism of GHG emissions trading between participating states. However, countries with emerging economies like China and India were exempted from obligatory cuts. To a great extent, it was the reason why the USA did not ratify the Kyoto Protocol and Canada withdrew from it. That is why, despite the wide implementation, the total GHG emissions boosted from 43.4 to 53.5 billion tonnes of $\mathrm{CO}_{2}$ equivalent with an increment of $23.7 \%$ for the period of the Kyoto Protocol validity in 1997-2012 (WB, 2019).

The Paris Agreement was sealed in 2015 and launched in November 2016 being ratified by over 180 countries. It is trying to arrange "holding the increase in the global average temperature to well below $2^{\circ} \mathrm{C}$ above pre-industrial levels and pursuing efforts to limit the temperature increase to $1.5^{\circ} \mathrm{C}$ above pre-industrial levels, recognizing ... common but differentiated responsibilities and respective capabilities, in the light of different national circumstances" (The Paris Agreement, 2015). Its ambitious focus was shifted towards a non-punitive and non-adversarial manner of delivering knowledge, sharing practices, mobilizing finance, and incentivizing public awareness to achieve a balance between resilience to climate change and a decrease in GHG emissions. The Paris Agreement emphasizes safeguarding food security and the specific status of the agriculture sector. On the one hand, it is among the sectors most sensitive and vulnerable to the adverse impacts of climate change. On the other hand, the plausible bounds set by the Paris Agreement would make agriculture the largest global methane and nitrous oxide emitter by mid-century. Certainly, climate change concerns Ukrainian agriculture in the capacity of an international food supplier. In compliance with the raised questions, we deem necessary to explore Ukrainian prospects in alleviating agricultural GHG emissions.

According to Myers et al. (2017), the global burden of adapting agricultural technologies and adjusting farm economics to climate uncertainty jeopardize providing food security for over 9 billion people by 2050. Global climate change translates into prolonged droughts, untypical floods, accelerated soil degradation, appearance of new pests and diseases, water scarcity, cuts in crop yields with lower concentration of protein, minerals, and vitamins, drops in animal productivities triggered by heat stress. Similarly, Frank et al.'s (2017) fulfilled scenario analysis focused on climate stabilization targets determined by taxes on GHG emissions from the agriculture sector and biomass demands. The considered feedback of global food security was expressed in losses in daily dietary energy, 
inevitable rise in food prices, and expected increase in the share of people's undernourishment. Campbell et al. (2016) emphasized that climate change influences all components of food security consistent with shifts in crop, livestock and fishery production quantities, food quality, distribution, affordability, allocation, utilization, waste, and consumption. Therefore, such challenges need integrated countermeasures of the global magnitude (Liu et al., 2019). For these purposes, Richards et al. (2018) detected plausible trajectories of mitigating agricultural GHG emissions with convergence in 2030, 2050 and 2100 . Their research gave evaluations over viable efforts shared among the developing countries and the developed world in order to facilitate climate change based on responsibility, capability, and equality subject to historical cumulative per capita emissions from agriculture and all economic sectors, gross domestic product, human development index, and population projections.

The Food and Agricultural Organization of the United Nations indicates the basic non- $\mathrm{CO}_{2}$ sources of Agricultural GHG Emissions involving source categories of enteric fermentation, manure management, synthetic fertilizers, rice cultivation, manure applied to soils and left on pasture, crop residues as well as cultivation of organic soils. The first three source categories are the major ones.

Enteric fermentation in digestive systems of ruminants causes emission of methane gas. Beef and dairy cattle, sheep, and goats are the prevalent sources of anthropogenic methane. In this case, contemporary developments present a wide variety of measurement methods to carry out GHG inventory. The most effective options are Respiration and Portable accumulation chambers, Ventilated hood, Sulphur hexaflouride, Polytunnel, and Micrometeorological approaches, Face mask, Greenfeed system, Sniffer and Hand made laser techniques, Mid infra-red spectroscopy and Fatty acid composition of milk, Statistical models (Hill et al., 2016; Patra, 2016). A prospective but expensive and time-consuming way to tackle the item in question is breeding of animals with a low $\mathrm{CH}_{4}$ production. A feasible short-term mean to diminish GHG emissions during enteric fermentation in ruminants is dietary manipulation which ensures livestock productivity and welfare. In this aspect, recent comprehensive studies by Grainger and Beauchemin (2011) and Haque (2018) spanned replacement of grass feed by maize silage, adding concentrates in the right proportion and composition, fat supplementation, organic acids, essential oils, ionophores, probiotics, exogenous enzymes, condensed tannins, and saponins.

The other essential animal source of GHG in the agriculture sector is anaerobic manure decomposition, which creates combined methane and nitrous oxide emissions. They appear in all stages of manure management such as livestock rearing, waste storage and treatment (Chadwick et al., 2011). A holistic examination of manure management was performed by $\mathrm{Pe}$ tersen et al. (2013) who compared pros and cons of GHG emissions for grazing and feedlot systems with Slurry lagoon, Liquid manure covering, Solid storage, Forced and Passive Composting, Drylot and Pasture deposition practices. A simple widespread way of manure utilization is its conversion into natural fertilizer. On the plus side, it corresponds to organic soil cultivation as well as maintains economical recycling of nutrients fed to livestock. On the minus side, such manure handling contradicts to the principles of precise crop husbandry when applied proportion and composition of nutrients must be stipulated by a crop variety and soil fertility. In our opinion, sustainable agriculture and progressive science promote the most encouraging option on minimizing GHG emissions from manure management through increasing its use for biogas production at least to $50 \%$ even in low-income areas in the near future (Sommer et al., 2013).

The issue of mitigating a contribution of synthetic fertilizers to the $\mathrm{GHG}$ emissions was a study topic of Hatfield and Venterea (2014) who focused on win-win trade-offs between increased plant uptakes and reduced environmental impact in the forms of nitrogen gaseous loss, surface runoff, or groundwater contamination. Butterbach-Bahl et al. (2013) investigated the ways to offset shortcomings of available techniques of measuring nitrous oxide soil-atmosphere interface involving the wind tunnels and the quantification of $\mathrm{N}_{2} \mathrm{O}$ fluxes via microbial analysis. Snyder (2016) and Rutting et al. (2018) explored the concept of "4R" N stewardship (right source, right rate, right time, right place) to avoid fertilizers' over-application, improve yield response and underpin farm economics coupled with alleviating natural drivers of climate footprint. 
In sum, the conducted multifaceted survey accompanied with data about ratifications of the UNFCCC and the Kyoto Protocol by the Laws of Ukraine in 1996 and 2004 gave us strong evidence that an ecological imperative of agricultural development in Ukraine supposes its commitment to mitigating $\mathrm{GHG}$ emissions and must be supported by a separate scientific examination.

\section{Methods}

\section{Our study aims to:}

identify a relative contribution of Ukraine to the world combined and agricultural GHG emissions to determine Ukrainian responsibility in mitigating climate change;

compare GHG regional accumulations from the primary agricultural sources to figure out priorities in alleviating agricultural $G H G$ emissions;

specify features of $\mathrm{GHG}$ emissions from the national agriculture consistent with the EU ecological tendencies to facilitate Ukrainian integration into European environment.

Table 1. Methodological scheme of research

\begin{tabular}{c|c|c}
\hline Task & Data size & Method \\
\hline 1 & $\begin{array}{r}178 \text { countries around } \\
\text { the world }\end{array}$ & The ranking method \\
\hline 2 & 24 regions in Ukraine & $\begin{array}{c}\text { The comparative } \\
\text { statistics analysis }\end{array}$ \\
\hline 3 & 28 EU Member States & $\begin{array}{c}\text { The method of the least } \\
\text { squares }\end{array}$ \\
\hline
\end{tabular}

Table 1 presents a brief methodological scheme of our research.

Namely, a theoretical base to the first research task was the ranking method (Thornley \& France, 2007). It was applied to information materials from the World Bank Data and the FAO Statistics Database referring to 178 countries each of which had a population over 400 thousand people. In this way, we compared quantities of global total and agricultural GHG emissions by country as well as their annual indicators per capita and per $\mathrm{km}^{2}$ of a land territory. The performed multi-criteria approach made it possible to expose the most insecure ecological zones and identify a Ukrainian environmental scenario.
A scientific background to the second research task was the comparative statistics analysis (Lee, 2014). It utilized information materials about 24 national regions available from the State Statistics Service of Ukraine and Ukraine's Greenhouse Gas Inventory for the UNFCCC. Such an approach enabled us to evaluate ruminant and combined livestock units as well as applied synthetic fertilizers by regions in Ukraine for revealing their key contributions to the national agricultural GHG emissions.

A theoretical platform to the third research task was the method of the least squares (Thornley \& France, 2007). It dealt with information materials collected from the EU Greenhouse Gas Inventory for the UNFCCC. To find the EU patterns closest to Ukrainian conditions, we considered shares of agricultural GHG emissions originated from crop and animal husbandry in the EU countries as well as their quantities of GHG emissions per unit of agricultural output.

It should be stipulated that the FAO and the UNFCCC inventory databases apply different methodologies of evaluating $\mathrm{GHG}$ emissions. Thus, sometimes their numbers do not coincide but both international databases are invaluable in view of ongoing world globalization (Babenko et al., 2019a). In cases of detailed considerations of Ukraine and the EU, we used country-specific values from the national combined reports.

Ultimately, to carry out the discussion of the results and conclude our study, we relied on the methods of synthesis and consolidation.

\section{Results and Discussion}

\section{Multi-criteria world ranking of GHG emissions}

The performed ranking calculations to the first research task, in agreement with multi-criteria approach of Gajos and Prandecki (2018), resulted in the next outcomes. Recently, China, the USA, India, Russia, Japan, Brazil, Germany, Indonesia, Canada, and Mexico have been the top-10 GHG polluters with 12,455, 6,673, 2,379, 2,199, $1,353,1,018,894,744,738$, and 733 million tonnes of emissions in $\mathrm{CO}_{2}$ equivalent, respectively. Together, these countries encompass $62.6 \%$ of the common world GDP and create $64.5 \%$ of the total global GHG emissions. The largest human insecurity was revealed 
in Kuwait, Brunei, Qatar, Australia, the United Arab Emirates, Bahrain, Oman, the USA, Libya, and Canada which emitted 46.1, 43.3, 30.2, 23.1, 22.9, 20.4, 20.3, 20.2, and 19.8 tonnes of GHG per capita per annum, respectively. At last, the top-10 environmental dangers were identified in Singapore, Bahrain, Kuwait, Malta, Qatar, South Korea, the Netherlands, Trinidad and Tobago, Israel, and Luxembourg, which had annual GHG emissions of 77,076, 43,554, 10,988, 9,426, 7,151, 6,742, 5,511, 5,034, 4,407, and 4,366 tonnes per $\mathrm{km}^{2}$ of a land territory, respectively (WB, 2019). Overall, the most unfavourable position was discovered to be in South Korea included in all three top20 lists by the analyzed indicators of GHG emissions.

The ranking calculations on agricultural GHG emissions led to the following findings. Currently, China, India, Brazil, the USA, Indonesia, Pakistan, Argentina, Australia, Ethiopia, and Mexico appear to be the top-10 $\mathrm{GHG}$ polluters with 687, 636, 452, 358, 172, 157, 114, 112, 100, and 89 million tonnes of emissions in $\mathrm{CO}_{2}$ equivalent, respectively. Together, they contain $53.4 \%$ of the world's population and are responsible for $54.5 \%$ of the agricultural GHG emissions on the planet. The largest human insecurity was detected in Mongolia, New Zealand, Uruguay, Ireland, the Central African Republic, Australia, Paraguay, South Sudan, Argentina, and Guyana, which emitted 8.1, 8.1, 6.9, 4.6, 4.5, 4.5, 3.9, 3.7, 2.5 and 2.5 tonnes of agricultural GHG per capita per annum, respectively. Finally, the top-10 environmental dangers were located in Bangladesh, the
Netherlands, Ireland, Malta, Singapore, Belgium, Luxembourg, Denmark, India, and Vietnam, which had annual agricultural $\mathrm{GHG}$ emissions of 593, 545, 325, 304, 300, 293, $229,227,214$, and 210 tonnes per $\mathrm{km}^{2}$ of a land territory, respectively (FAO, 2019). It should be stressed that in both cases China, India, Brazil, the USA, Indonesia, and Mexico were principal sources of GHG emissions. Australia had top-10 levels of GHG emissions per capita. The Netherlands, Malta, Singapore, and Luxembourg occurred to be among the named prevalent emitters by GHG quantities per $\mathrm{km}^{2}$ of their land territories.

Evidently, Ukrainian ecology encounters the same challenges. Indeed, the national economy ranks as the $20^{\text {th }}$ GHG emitter (Fig. 1). It pronounces a sharp discrepancy with the $57^{\text {th }}$ rank in the list of countries by GDP. One of evident explanations of such a state is connected with financial damages caused by the shadow economy as well as applying outdated energy intensive technologies and managerial methods (Babenko et al., 2019b; Khalatur et al., 2019; Velychko, 2013). Ukrainian positions by GHG emissions per capita and per $\mathrm{km}^{2}$ of a land territory are more adequate since they correspond to the $43^{\text {rd }}$ and $47^{\text {th }}$ ranks among the considered 178 countries. The national inventory for the UNFCCC assessed total Ukrainian GHG emissions to equal to 320.9 million tonnes which decreased by $66 \%$ below the 1990 level of 944.6 million tonnes in $\mathrm{CO}_{2}$ equivalent (NCGHGEl, 2019). Ecology of

Fig. 1. Multi-criteria rank evaluation of GHG emissions in Ukraine.

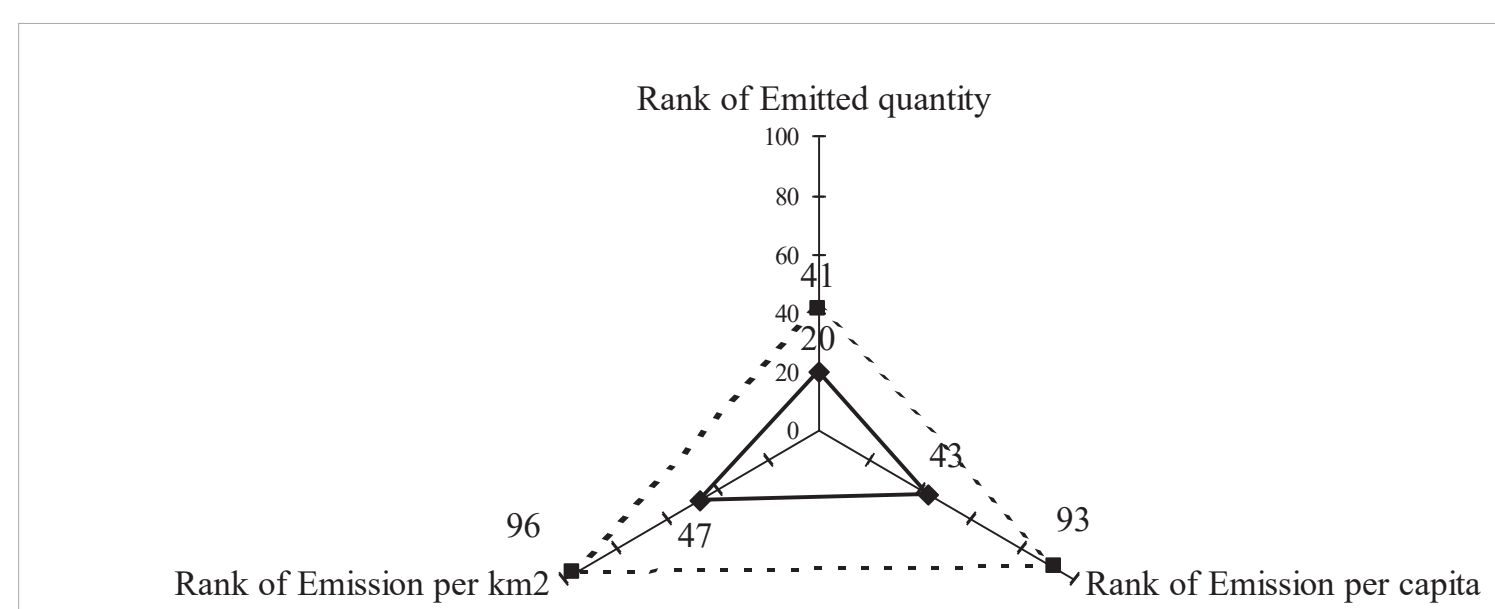

$\neg$ Total GHG Emission $\quad-\bullet-$ Agricultural GHG Emission 
Ukrainian agriculture looks much better (Fig. 1). Namely, for 1992-2006, there was a favourable sharp drop in GHG emissions by 2.6 times from 75 to 29 million tonnes. Until now, this indicator remains relatively unchanged decreasing down to 27 million tonnes in $\mathrm{CO}_{2}$ equivalent. In consequence, being $33^{\text {rd }}$ by population, Ukraine is a $41^{\text {st }}$ source of agricultural emissions. Their quantities per capita and per $\mathrm{km}^{2}$ of a land territory are ranked 93 and 96 . At the same time, the national inventory for the UNFCCC evaluated agricultural GHG emissions like 39.1 million tonnes in $\mathrm{CO}_{2}$ equivalent that is $56.3 \%$ below the 1990 level (NCGHGEI, 2019).

\section{Regional distribution by sources of agricultural GHG}

A more detailed inventory of agricultural GHG emissions in Ukraine was proceeded within the second research task. A contribution of the agriculture sector to the total GHG emissions in Ukraine accounted for $12.2 \%$ in 2017. Table 2 and Fig. 2 assemble the results of calculations dedicated to identifying the main sources of agricultural GHG emissions by Ukrainian regions. Numbers related to enteric fermentation and manure management were obtained via regional shares of kept livestock as well as $\mathrm{CH}_{4}$ and $\mathrm{N}_{2} \mathrm{O}$ emissions by kind of animal (NCGHGEl, 2019). For these purposes, we considered beef cattle, dairy cows, sheep, goats, swine, rabbits, horses, and poultry. The latter are mostly broilers and laying hens in Ukraine.

Approximately $50 \%$ of $\mathrm{GHG}$ emissions referring to agricultural soils originate from crop residues and mineralization/immobilization associated with loss or gain of soil organic matter. Despite essential nitrous oxide contribution, above- and below-ground crop residues are responsible for humification of dead organic matter. This natural process is extremely important for preserving Ukrainian black soils and offsetting low precipitation on rain-fed lands. Thus, our research does not delve into cutting ploughing crop residues in Ukraine like infeasible in the foreseeable future. In turn, we focused on applying synthetic fertilizers, which deposit around $24 \%$ of GHG emissions linked with agricultural soils. Data on GHG emissions derived from synthetic fertilizers were assessed by means of their quantities applied to $38.8 \%$

Fig. 2. Ranges of agricultural GHG emissions by Ukrainian regions.

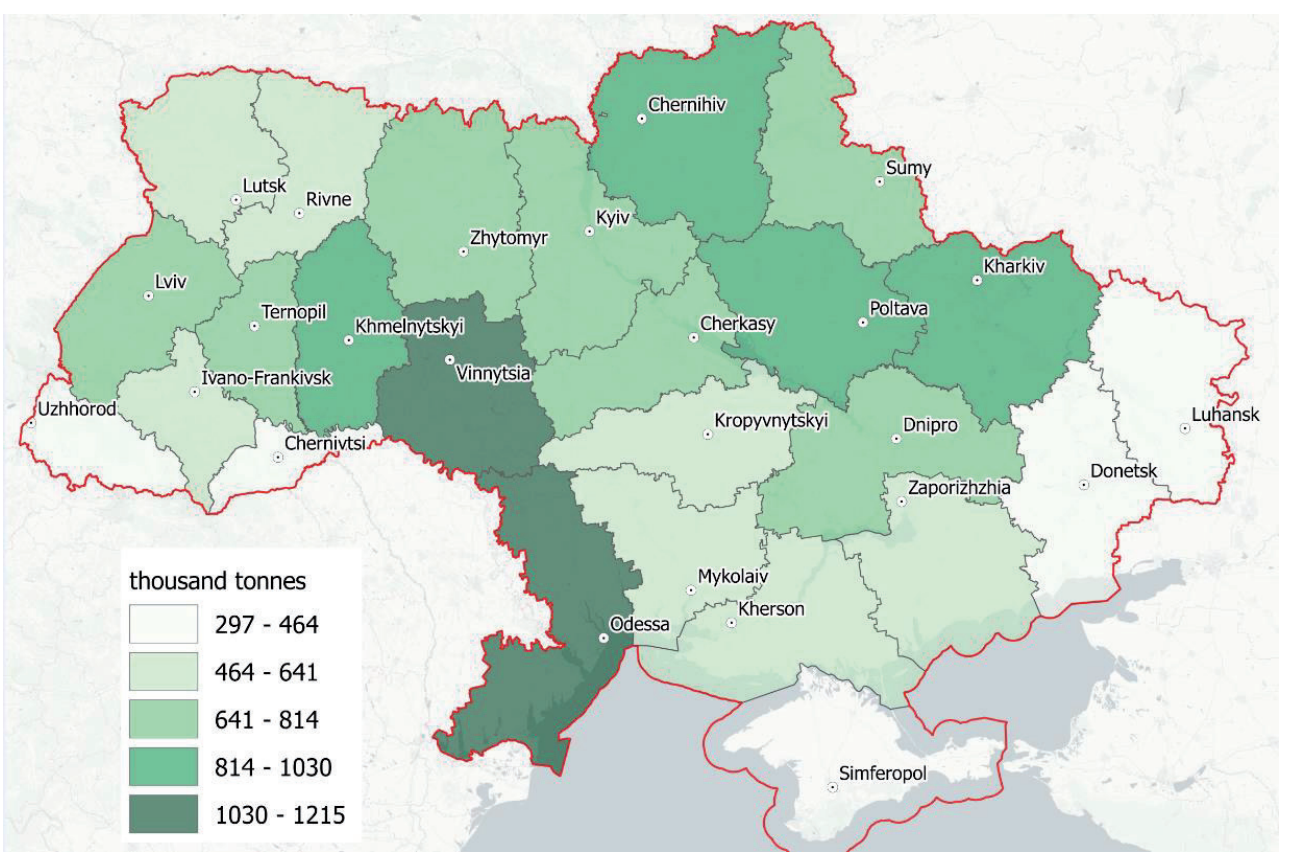


Table 2. Agricultural GHG emissions by regions of Ukraine

\begin{tabular}{|c|c|c|c|}
\hline \multirow{2}{*}{ Region } & \multicolumn{3}{|c|}{ GHG emissions (in thousand tonnes of $\mathrm{CO} 2$ equivalent) caused by } \\
\hline & enteric fermentation & manure management & synthetic fertilizers \\
\hline Cherkasy & 370.7 & 112.9 & 330.4 \\
\hline Chernihiv & 432.2 & 76.9 & 459.7 \\
\hline Chernivtsi & 223.6 & 46.5 & 26.6 \\
\hline Crimea (Simferopol) & no data & no data & no data \\
\hline Dnipropetrovsk (Dnipro) & 315.4 & 98.8 & 365.5 \\
\hline Donetsk & 168.1 & 74.3 & 193.2 \\
\hline Ivano-Frankivsk & 361.0 & 82.8 & 69.6 \\
\hline Kharkiv & 425.6 & 82.2 & 384.7 \\
\hline Kherson & 256.7 & 49.5 & 198.4 \\
\hline Khmelnytskiy (Kropyvnytskyi) & 573.4 & 114.1 & 336.5 \\
\hline Kirovohrad & 229.2 & 57.1 & 354.4 \\
\hline Kyiv & 302.8 & 120.9 & 306.9 \\
\hline Luhansk & 121.8 & 21.0 & 181.1 \\
\hline Lviv & 461.0 & 113.5 & 204.2 \\
\hline Mikolayiv & 259.9 & 43.5 & 291.9 \\
\hline Odessa & 475.7 & 79.8 & 502.6 \\
\hline Poltava & 554.3 & 108.8 & 367.3 \\
\hline Rivne & 338.2 & 77.4 & 123.8 \\
\hline Sumy & 350.4 & 61.5 & 369.8 \\
\hline Ternopil & 371.4 & 88.5 & 268.8 \\
\hline Vinnytsya & 591.6 & 136.8 & 486.8 \\
\hline Volyn (Lutsk) & 368.0 & 86.4 & 166.2 \\
\hline Zakarpattya (Uzhhorod) & 377.6 & 75.0 & 11.2 \\
\hline Zaporizhzhia & 237.0 & 57.2 & 334.4 \\
\hline Zhytomyr & 489.6 & 87.1 & 199.6 \\
\hline
\end{tabular}

of Ukrainian agricultural areas in 2018. A steep decline in using organic fertilizers allowed us to neglect their entire effect on GHG emissions. Really, a current share of Ukrainian agricultural lands nourished by organic fertilizers diminished to $1.9 \%$ or by 11.2 percentage points below 1990 level (SSSU, 2019).

Fig. 2 depicts Vinnytsya and Odessa regions to be the largest combined contributors to domestic agricultural GHG emissions by the analyzed source categories. However, low GHG emissions in Chernivtsi, Donetsk, Luhansk, and Zakarpattya areas mean weak agricultural development rather than applying ecological technologies of advanced farming.

Table 2 revealed that the worst conditions connected with enteric fermentation were detected in Vinnytsya, Khmelnytskiy, and Poltava areas. The largest GHG footprints triggered by manure management took place in Vinnytsya, Kyiv, and Khmelnytskiy regions. Meanwhile, synthetic fertilizers generated the most GHG emissions in Odessa, Vinnytsya, and Chernihiv areas.

As a matter of fact, the paramount reason of the described picture is keeping $65.9 \%$ of cattle as well as 
$86.3 \%$ of sheep and goats in small households. They demonstrate enhanced enteric fermentation due to practicing cheaper livestock diets containing just $21 \%$ of concentrated and succulent fodders compared with $60 \%$ in Ukrainian agricultural enterprises. Besides, restricted investment capabilities force the national households mostly to leave manure on pasture instead of its solid storage. The identical cause explains improper application of synthetic fertilizers unbalanced with soil tests and crop nutrient demands (Vasylieva, 2019a). In our opinion, the plausible options for relevant improvements may be conveyed from agricultural leaders among the EU Member States. Such prospects were disclosed within the third research task.

\section{EU profile of agricultural GHG emissions}

Ukrainian commitment to European integration implies that foreign ways and approaches to mitigating agricultural GHG emissions can be successfully transferred from the EU countries. They strive to ensure "the timeliness, transparency, accuracy, consistency, comparability and completeness" of monitoring and reporting their progress in a uniform way towards providing effective agricultural production in line with preserving the environment and the climate (EEA, 2019). For the last almost thirty years, the EU Member States demonstrated significant cuts in total and agricultural GHG emissions which are by $23.4 \%$ and $19.1 \%$ below the 1990 level. Moreover, by 2030, the EU set an ambitious target of cutting $\mathrm{GHG}$ emissions at least by $40 \%$. Now the $\mathrm{EU}$ agricultural $\mathrm{CH}_{4}, \mathrm{~N}_{2} \mathrm{O}$ and $\mathrm{CO}_{2}$ emissions in relative terms account for $47.4 \%, 72.1 \%$, and $0.26 \%$ of total respective emissions (EEA, 2019). By comparison, the agriculture sector in Ukraine is responsible for $15 \%$ of methane and $86 \%$ of nitrous oxide emissions nationwide (NCGHGEI, 2019). In absolute terms, Ukrainian agricultural $\mathrm{GHG}$ emissions in $\mathrm{CO}_{2}$ equivalent follow after 76.2 million tonnes in France, 66.3 million tonnes in Germany, 41.2 million tonnes in the United Kingdom, and 39.5 million tonnes in Spain.

Table 3 incorporates results on selecting patterns best suitable to the Ukrainian condition by shares of animal and crop outputs, their GHG emissions as well as the ones per EUR million of agricultural production. Hence, the performed comparison encourages Ukrainian agriculture to design a development strategy tracing the closest Bulgaria and Lithuania, which differ from the national aggregate indicator by 8.3 and 27.4 percentage points, respectively.

According to the EU tendencies, GHG emissions in Ukrainian agriculture should expect an increase created by an upward trend in applying synthetic fertilizers. We guess it to be inevitable since their quantity used in Ukraine per hectare of agricultural lands is less than in all EU countries. Inter alia, a lack of applied crop nutrients results in poor yields of cereals and, in particular, wheat. They are lower than those by $10-110 \%$ and $3-149 \%$ in 20 and 22 EU countries, respectively (Vasylieva, 2018). However, the reasonable limits over applying fertilizers were established by the Nitrate Directive in the frame of "greening" the EU Common Agricultural Policy (EEA, 2019).

Productions of meat and dairy in Ukraine leave much to be desired and do not meet demands of a healthy rational diet. By comparison, their outputs per capita in the EU were $88 \mathrm{~kg}$ and $336 \mathrm{~kg}$, but only $54 \mathrm{~kg}$ and $230 \mathrm{~kg}$ in Ukraine for 2018, respectively (Vasylieva, 2019b). Consequently, looking forward to a positive scenario of recovering food security in animal husbandry, Ukrainian agriculture should focus on the advanced technologies in manure management to prevent a collateral raise in GHG emissions and learn by example of the EU countries. In 2017, their systems of handling decomposition of manure nitrogen were quiet diversified including anaerobic lagoon, composting, daily spread, digesters, liquid system, solid storage and dry lot (EEA, 2019).

The national prospects of stable GHG emissions from enteric fermentation are rather optimistic. Firstly, it should be noted that shares of bovine meat in Ukraine and the $\mathrm{EU}$ are almost equal, i.e., $16 \%$ and $17 \%$. In our opinion, the future raise in Ukrainian meat production would be achieved by means of the most affordable poultry (chicken) meat. Currently, its national share of production and per capita quantity were $54 \%$ and $29 \mathrm{~kg}$. Meanwhile, the similar indicators in the EU amounted to $31 \%$ and $27 \mathrm{~kg}$ in 2018 (FAO, 2019). Secondly, an annual yield of 4,922 kg of milk per cow in Ukraine is less than those by $6-98 \%$ in 25 EU countries except 
for Bulgaria, Croatia, and Romania. Ukraine can reach the EU level in milk output via enhancing cows' productivity up to $7,124 \mathrm{~kg}$ or by $45 \%$ with an unchanged herd size. In such a case, improved feeding and breeds may eliminate a potential increase in GHG emissions. Now, a major share of around $67 \%$ in dairy herd belongs to Ukrainian Dairy Black and Red Motley breeds with medium milk productivity. But a structural part of Holstein breed with a high milk yield accounted for merely 11\% (NCGHGEI, 2019). Here, Ukraine should track progress of the EU countries which maintained an essential reduction by 42.9 million tonnes or $20.7 \%$ in GHG emissions derived from beef and dairy cattle for the period 1990-2017 (EEA, 2019).

Table 3. Relative deviations between agricultural GHG emissions in the EU countries and Ukraine

\begin{tabular}{|c|c|c|c|c|c|c|}
\hline \multirow{2}{*}{ Country } & \multicolumn{2}{|c|}{$\begin{array}{l}\text { Share (in \%) of GHG } \\
\text { emissions from }\end{array}$} & \multicolumn{2}{|c|}{ Share (in \%) of } & \multirow{2}{*}{$\begin{array}{l}\text { Share (in \%) of agricultural GHG } \\
\text { emissions per output EUR million } \\
\text { relative to Ukraine }\end{array}$} & \multirow{2}{*}{$\begin{array}{l}\text { Aggregate deviation } \\
\text { (in p.p.) relative to } \\
\text { Ukraine }\end{array}$} \\
\hline & $\begin{array}{c}\text { Animal } \\
\text { husbandry }\end{array}$ & $\begin{array}{c}\text { Crop } \\
\text { husbandry }\end{array}$ & $\begin{array}{l}\text { Animal } \\
\text { output }\end{array}$ & $\begin{array}{l}\text { Crop } \\
\text { output }\end{array}$ & & \\
\hline Ukraine & 27.1 & 72.9 & 28.0 & 72.0 & 100.0 & - \\
\hline Austria & 70.6 & 29.4 & 54.2 & 45.8 & 66.9 & 79.04 \\
\hline Belgium & 64.4 & 35.6 & 57.0 & 43.0 & 73.9 & 71.72 \\
\hline Bulgaria & 32.2 & 67.8 & 26.2 & 73.8 & 103.3 & 8.26 \\
\hline Croatia & 59.2 & 40.8 & 38.9 & 61.1 & 85.3 & 50.17 \\
\hline Cyprus & 75.6 & 24.4 & 60.9 & 39.1 & 44.1 & 99.95 \\
\hline the Czech Republic & 53.4 & 46.6 & 40.9 & 59.1 & 110.2 & 42.66 \\
\hline Denmark & 58.8 & 41.2 & 65.1 & 34.9 & 62.5 & 78.59 \\
\hline Estonia & 48.6 & 51.4 & 54.2 & 45.8 & 103.7 & 48.13 \\
\hline Finland & 43.5 & 56.5 & 62.5 & 37.5 & 108.6 & 54.70 \\
\hline France & 53.7 & 46.3 & 39.6 & 60.4 & 70.2 & 50.71 \\
\hline Germany & 52.9 & 47.1 & 51.1 & 48.9 & 76.0 & 54.60 \\
\hline Greece & 57.9 & 42.1 & 24.6 & 75.4 & 45.8 & 69.66 \\
\hline Hungary & 45.4 & 54.6 & 37.7 & 62.3 & 55.3 & 53.41 \\
\hline Ireland & 69.0 & 31.0 & 77.7 & 22.3 & 147.4 & 103.44 \\
\hline Italy & 66.0 & 34.0 & 35.6 & 64.4 & 41.0 & 81.34 \\
\hline Latvia & 38.0 & 62.0 & 42.3 & 57.7 & 132.2 & 40.99 \\
\hline Lithuania & 44.6 & 55.4 & 36.0 & 64.0 & 97.6 & 27.36 \\
\hline Luxembourg & 70.8 & 29.2 & 60.5 & 39.5 & 110.8 & 77.80 \\
\hline Malta & 72.2 & 27.8 & 57.8 & 42.2 & 34.1 & 100.87 \\
\hline the Netherlands & 70.3 & 29.7 & 45.6 & 54.4 & 45.1 & 85.83 \\
\hline Poland & 52.4 & 47.6 & 53.8 & 46.2 & 79.3 & 55.09 \\
\hline Portugal & 66.5 & 33.5 & 39.8 & 60.2 & 59.1 & 71.09 \\
\hline Romania & 67.3 & 32.7 & 25.8 & 74.2 & 73.3 & 62.82 \\
\hline Slovakia & 49.1 & 50.9 & 40.3 & 59.7 & 72.5 & 45.02 \\
\hline Slovenia & 73.0 & 27.0 & 49.0 & 51.0 & 89.6 & 72.19 \\
\hline Spain & 65.8 & 34.2 & 38.5 & 61.5 & 49.1 & 76.18 \\
\hline Sweden & 50.3 & 49.7 & 49.9 & 50.1 & 74.6 & 51.82 \\
\hline the United Kingdom & 69.1 & 30.9 & 59.8 & 40.2 & 86.8 & 75.65 \\
\hline
\end{tabular}




\section{Conclusions}

The past four years had the highest average temperature in the recorded history. Global warming as a part of general climate change and its major anthropogenic contributor in the form of GHG emission need special attention. It is undeniable because, to a great extent, the named challenge affects the agriculture sector and exposes countries to food insecurity. The conducted research convinced that mitigation of GHG effect demands permanent monitoring over its total emissions, quantities per capita, and per $\mathrm{km}^{2}$ of a land territory. To benefit from the global combined efforts, such evaluations should be performed not only in absolute terms but also in relative ranks among all countries.

To drive a decrease in the national agricultural GHG impact we propose horizontal and vertical analyses of regional emitters. The horizontal analysis is targeted

\section{References}

Babenko V., Perevozova I., Mandych O., Kvyatko T., Maliy O., Mykolenko, I. (2019a) World informatization in conditions of international globalization: Factors of influence. Global Journal of Environmental Science and Management 5, Special Issue, 172179. http://dx.doi.org/10.22034/gjesm.2019.05.SI.19.

Babenko V., Sidorov V., Koniaieva Y., Kysliuk L. (2019b) Features in scientific and technical cooperation in the field of non-conventional renewable energy. Global Journal of Environmental Science and Management 5, Special Issue, 105-112. http://dx. doi.org/10.22034/gjesm.2019.05.SI.12.

Butterbach-Bahl K., Baggs E.M., Dannenmann M., Kiese R., Zechmeister-Boltenstern S. (2013) Nitrous Oxide Emissions from Soils: How Well Do We Understand the Processes and Their Controls? Philosophical Transactions of the Royal Society B, Biological Science 368 (1621): 20130122. https:// doi.org/10.1098/rstb.2013.0122. https://doi.org/10.1098/ rstb.2013.0122

Campbell B. M., Vermeulen S. J., Aggarwal P. K., Corner-Dolloff C., Girvetz E., Loboguerrero A. M., Ramirez-Villegas J., Rosenstock T., Sebastian L., Thornton P. K., Wollenberg E. (2016) Reducing Risks to Food Security from Climate Change. Global Food Security 11, 34-43. https://doi.org/10.1016/j.gfs.2016.06.002. https://doi.org/10.1016/j.gfs.2016.06.002

Chadwick D., Sommer S., Thorman R., Fangueiro D., Cardenas L., Amon B., Misselbrook T. (2011) Manure management: im- at setting priorities between the core source categories of enteric fermentation, manure management, and application of synthetic fertilizers to diminish GHG emissions in each area. The vertical analysis is focused on comparing ranks and shares of GHG footprint by the basic agricultural sources among the domestic regions.

Our findings confirmed that mitigation of agricultural GHG emissions in Ukraine would gain from the relevant EU experiences like expanding practices of smart sustainable agriculture, switching to renewable sources of energy, fostering high productivity, maintaining minimal loss of harvest, and tackling diets' imbalances. This approach will bridge knowledge and technology gaps in shrinking GHG emissions from the national agriculture and prepare it for meeting the ecological challenge of climate change and providing imperative food security.

plications for greenhouse gas emissions. Animal Feed Science and Technology 166-167, 514-531. https://doi.org/10.1016/j. anifeedsci.2011.04.036. https://doi.org/10.1016/j.anifeedsci.2011.04.036

EEA (European Environment Agency) (2019) Annual European Union Greenhouse Gas Inventory 1990-2017 and Inventory Report 2019. Submission under the United Nations Framework Convention on Climate Change and the Kyoto Protocol. Brussels: European Commission, 940 p. Available at: https://www. eea.europa.eu/ (accessed 12 July 2019).

FAO (Food and Agriculture Organization) (2019) Statistics on Agri-Environmental Indicators and Emissions of the Food and Agriculture Organization of the United Nations. Available at: http://www.fao.org/ (accessed 30 August 2019).

Frank S., Havlík P., Soussana J.-F., Levesque A., Valin H., Wollenberg E., Kleinwechter U., Fricko O., Gusti M., Herrero M., Smith P., Hasegawa T., Kraxner F., Obersteiner M. (2017) Reducing greenhouse gas emissions in agriculture without compromising food security? Environmental Research Letters 12 (10), Article 105004. https://doi.org/ 10.1088/1748-9326/ aa8c83. https://doi.org/10.1088/1748-9326/aa8c83

Gajos E.M., Prandecki K. (2018) Multi-criteria approach to greenhouse gases emission reduction. Abstracts of the International Conference 'Agricultural GHG Emissions and Food Security - Connecting research to policy and practice', Septem- 
ber, 10-13, 2018, Berlin, Germany. Available at: https://www. agrighg-2018.org/fileadmin/ghg-agriculture/Agri GHG_Volume_of_Abstracts.pdf (accessed 25 July 2019).

Grainger C., Beauchemin K. A. (2011) Can enteric methane emissions from ruminants be lowered without lowering their production? Animal Feed Science and Technology 166-167, 308-320. https://doi.org/ 10.1016/j.anifeedsci.2011.04.021 https://doi.org/10.1016/j.anifeedsci.2011.04.021

Haque M. N. (2018) Dietary manipulation: a sustainable way to mitigate methane emissions from ruminants. Journal of Animal Science and Technology 60 (1), Article 15. https://doi. org/10.1186/s40781-018-0175-7. https://doi.org/10.1186/ s40781-018-0175-7

Hatfield J. L., Venterea R. T. (2014) Enhanced Efficiency Fertilizers: a Multi-Site Comparison of the Effects on Nitrous Oxide Emissions and Agronomic Performance. Agronomy Journal 106 (2), 679-680. https://doi.org/10.2134/agronj2013.0900. https://doi.org/10.2134/agronj2013.0900

Hill J., McSweeney C., Wright A. D. G., Bishop-Hurley G., Kalantar-Zadeh K. (2016) Measuring methane production from ruminants. Trends in Biotechnology 34 (1), 26-35. https://doi. org/10.1016/j.tibtech.2015.10.004. https://doi.org/10.1016/j. tibtech.2015.10.004

Khalatur S., Radzevicius G., Velychko L., Fesenko V., Kriuchko L. (2019) Global deoffshorization and its impact on the national and regional economies of Eastern European countries. Problems and Perspectives in Management 17 (3), 293-305. https://doi. org/10.21511/ppm.17(3).2019.24 https://doi.org/10.21511/ ppm.17(3).2019.24

Lee H. (2014) Foundations of Applied Statistical Methods, New York: Springer, 161 p. ISBN 3319024019.

Liu Y., Tang H., Muhammad A., Huang G. (2019) Emission mechanism and reduction countermeasures of agricultural greenhouse gases - a review. Greenhouse Gases: Science and Technology 9 (2), 160-174. https://doi.org/10.1002/ghg.1848. https://doi.org/10.1002/ghg.1848

Myers S. S., Smith M. R., Guth S., Golden C. D., Vaitla B., Mueller N. D., Dangour A. D., Huybers P. (2017) Climate Change and Global Food Systems: Potential Impacts on Food Security and Undernutrition. Annual Review of Public Health 38, 259-277. https://doi.org/10.1146/annurev-publhealth-031816-044356.

NCGHGEI (National Center for GHG Emission Inventory) (2019). Ukraine's Greenhouse Gas Inventory 1990-2017. Annual National Inventory Report for Submission under the United Nations Framework Convention on Climate Change and the Kyoto Protocol. Kyiv: Ministry of Ecology and Natural Resources of Ukraine, 504 p. Avail- able at: https://menr.gov.ua/ (accessed 28 August 2019).

Patra A.P. (2016) Recent Advances in Measurement and Dietary Mitigation of Enteric Methane Emissions in Ruminants. Frontiers in Veterinary Science 3, Article 39. https://doi. org/10.3389/fvets.2016.00039.

Petersen S. O., Blanchard M., Chadwick D., Del Prado A., Edouard N., Mosquera J., Sommer S. G. (2013) Manure management for greenhouse gas mitigation. Animal 7 (s2), 266-282. https://doi. org/10.1017/S1751731113000736.

Richards M. B., Wollenberg E., van Vuuren D. (2018) National Contributions to Climate Change Mitigation from Agriculture: Allocating a Global Target. Climate Policy 18 (10), 1271-1285. https://doi.org/10.1080/14693062.2018.1430018.

Rutting T., Aronsson H., Delin S. (2018) Efficient Use of Nitrogen in Agriculture. Nutrient Cycling in Agroecosystems 110 (1), 1-5. https://doi.org/10.1007/s10705-017-9900-8.

Sommer S. G., Christensen M. L., Schmidt T., Jensen L. S. (Eds) (2013) Animal manure recycling: treatment and management. Hoboken: John Wiley \& Sons Ltd, 382 p. https://doi. org/10.1002/9781118676677.

Snyder C.S. (2016) Enhanced nitrogen fertilizer technologies support the '4R' concept to optimize crop production and minimize environmental losses. Proceedings of the International Nitrogen Initiative Conference, 'Solutions to improve nitrogen use efficiency for the world', December, 4-8, 2016, Melbourne, Australia. Available at: http://www.ini2016.com/pdf-papers/ INI2016_Snyders_Clifford.pdf (accessed 29 July 2019).

SSSU (State Statistics Service of Ukraine) (2019) Agriculture in Ukraine. Yearbook Statistics. Available at: http://www.ukrstat. gov.ua/ (accessed 15 July 2019).

The Kyoto Protocol (1998) Extension of the United Nations Framework Convention on Climate Change. Available at: https://unfccc.int/resource/docs/convkp/kpeng.pdf (accessed 15 August 2019).

The Paris Agreement (2015) Extension of the United Nations Framework Convention on Climate Change. Available at: https://unfccc.int/sites/default/files/english_paris_agreement.pdf (accessed 02 August 2019).

Thornley J. H. M., France J. (2007) Mathematical Models in Agriculture: Quantitative Methods for the Plant, Animal and Ecological Sciences, Trowbridge: CABI, 906 p. ISBN 085199010X. https://doi.org/10.1079/9780851990101.0000

WB (The World Bank) (2019) Open Data. Climate Change Indicators. Available at: https://data.worldbank.org/ (accessed 09 August 2019). 
UNFCCC (United Nations Framework Convention on Climate Change) (2019) The Secretariat on Climate Change of the United Nations. Available at: https://unfccc.int/ (accessed 19 July 2019).

Vasylieva N. (2018) Ukrainian Agricultural Contribution to the World Food Security: Economic Problems and Prospects. Montenegrin Journal of Economics 14 (4), 215-224. https:// doi.org/10.14254/1800-5845/2018.14-4.15..https://doi. org/10.14254/1800-5845/2018.14-4.15

Vasylieva N. (2019a) Improvement of Agricultural Manage- ment: Functional Comparative Approach, Montenegrin Journal of Economics 15 (1), 227-238. https://doi.org/10.14254/18005845/2019.15-1.17

Vasylieva N. (2019b) Problems and Prospects of Food Security in Ukraine. Bulgarian Journal of Agricultural Science 25 (4), 668-676. ISSN 0310-0351, E- ISSN 2534-983X.

Velychko O. P. (2013) Methodology for estimation of enterprise logistics development. Actual Problems of Economics 146 (8), 45-54. ISSN 1993-6788. 